\title{
Treatment of disseminated granuloma annulare with fumaric acid esters
}

\author{
Alexander Kreuter, Thilo Gambichler*, Peter Altmeyer and \\ Norbert H Brockmeyer
}

\author{
Address: Department of Dermatology, Ruhr-University Bochum, Gudrunstrasse 56, 44791 Bochum, Germany \\ E-mail: Alexander Kreuter - a.kreuter@derma.de; Thilo Gambichler* - t.gambichler@derma.de; Peter Altmeyer - p.altmeyer@derma.de; \\ Norbert H Brockmeyer - n.brockmeyer@derma.de \\ ${ }^{*}$ Corresponding author
}

Published: 19 March 2002

BMC Dermatology 2002, 2:5

This article is available from: http://www.biomedcentral.com/I47/-5945/2/5

(c) 2002 Kreuter et al; licensee BioMed Central Ltd. Verbatim copying and redistribution of this article are permitted in any medium for any purpose, provided this notice is preserved along with the article's original URL.

Received: 19 December 2001

Accepted: 19 March 2002

\begin{abstract}
Background: Granuloma annulare is a granulomatous disease of unknown etiology. Various therapies have been tried in disseminated granuloma annulare (DGA), including corticosteroids, several variants of psoralen plus ultraviolet-A radiation, ultraviolet- Al radiation, systemic retinoids, and dapsone, with variable success. We report a patient with recalcitrant DGA who was treated with fumaric acid esters (FAE).
\end{abstract}

Case presentation: A 40-year old Caucasian woman presented with a 25-year history of recalcitrant DGA. On both legs and the abdomen there were erythematous annular plaques. She was treated with FAE in tablet form using two formulations differing in strength (low strength tablets: $30 \mathrm{mg}$ dimethylfumarate, $67 \mathrm{mg}$ monoethylfumarate $\mathrm{Ca}$ salt, $5 \mathrm{mg}$ monoethylfumarate $\mathrm{Mg}$ salt, $3 \mathrm{mg}$ monoethylfumarate $\mathrm{Zn}$ salt; high strength tablets: $120 \mathrm{mg}$ dimethylfumarate, $87 \mathrm{mg}$ monoethylfumarate $\mathrm{Ca}$ salt, $5 \mathrm{mg}$ monoethylfumarate $\mathrm{Mg}$ salt, $3 \mathrm{mg}$ monoethylfumarate $\mathrm{Zn}$ salt). After three-month therapy, an almost complete clearance of skin lesions was achieved. With the exception of temporary lymphopenia, no adverse effects were observed. The patient remained in remission during a six-month follow up period.

Conclusions: Our observation has demonstrated that FAE is a potentially beneficial therapeutic option for patients with recalcitrant DGA. However controlled trials are necessary to fully explore the efficacy, optimal dosage, and safety of FAE in the management of DGA.

\section{Background}

Granuloma annulare is a granulomatous disease of unknown etiology. Disseminated granuloma annulare (DGA) is characterized by a chronic course of disease and frequent association with systemic disorders such as diabetes mellitus. Although spontaneous resolution can occur in some cases various therapies have been tried in DGA, including corticosteroids, several variants of psor- alen plus ultraviolet-A radiation, ultraviolet- A1 radiation, systemic retinoids, and dapsone, with variable success [15]. We report a patient with recalcitrant DGA who was treated with fumaric acid esters (FAE).

\section{Case presentation}

A 40-year old Caucasian woman presented with a 25-year history of DGA on both legs. Since one year, she also had 


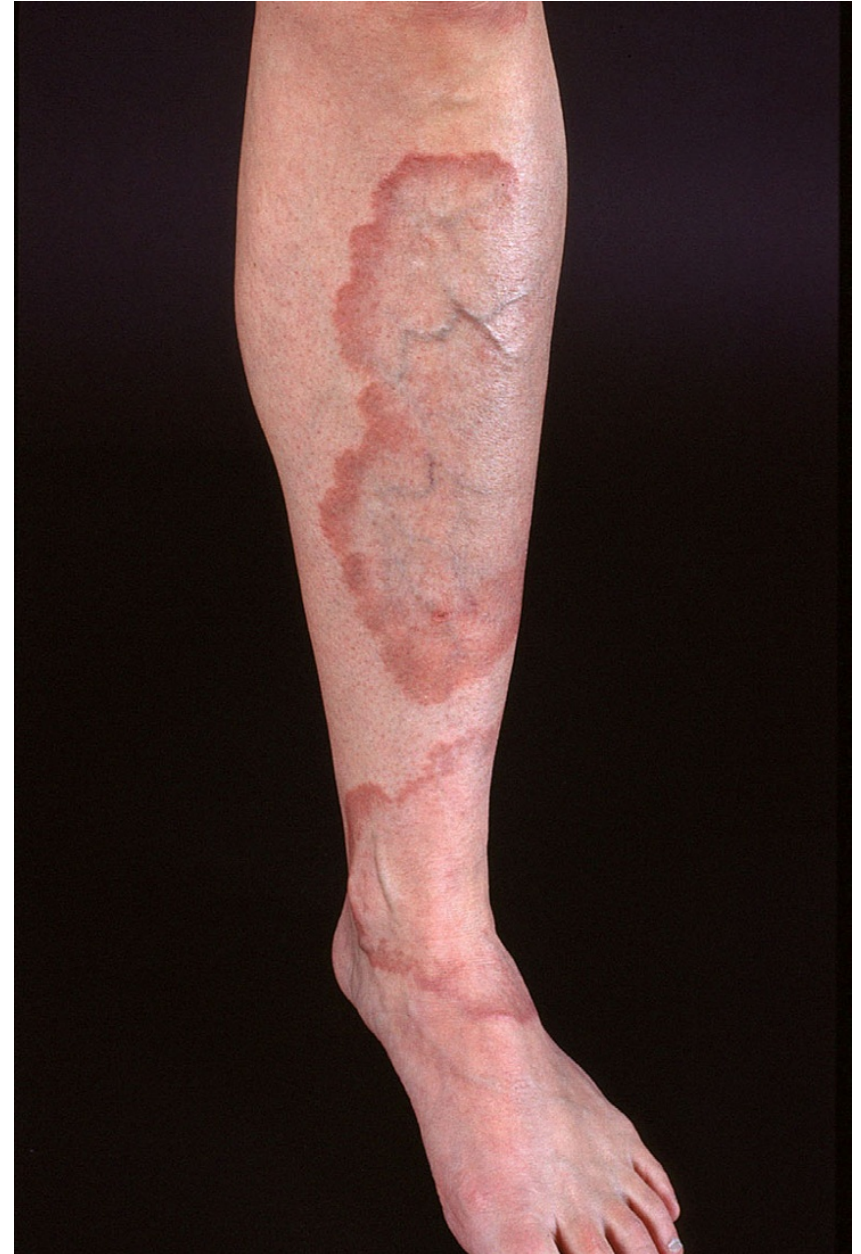

Figure I

Long-standing disseminated granuloma annulare on the left leg.

lesions on the abdomen. Previous treatments with various therapeutic modalities (e.g., corticosteroids, dapsone, and bath psoralen plus ultraviolet-A radiation) were ineffective. On examination, she had erythematous annular plaques on the abdomen and on both legs (Fig. 1). Histopathologic examination of a punch biopsy specimen from the left leg revealed a normal epidermis. Below the epidermis there was mild collagen degeneration surrounded by palisading inflammatory cells. The infiltrates consisted of a mixture of monocytes, histiocytes, and occasional giant cells. These findings were consistent with the diagnosis of DGA. Complete work-up did not reveal evidence of malignancies, infections, and internal diseases such as diabetes mellitus.

Since the disease had been recalcitrant to various conventional therapies, we decided to start oral treatment with fumaric acid esters. The patient was treated with FAE in

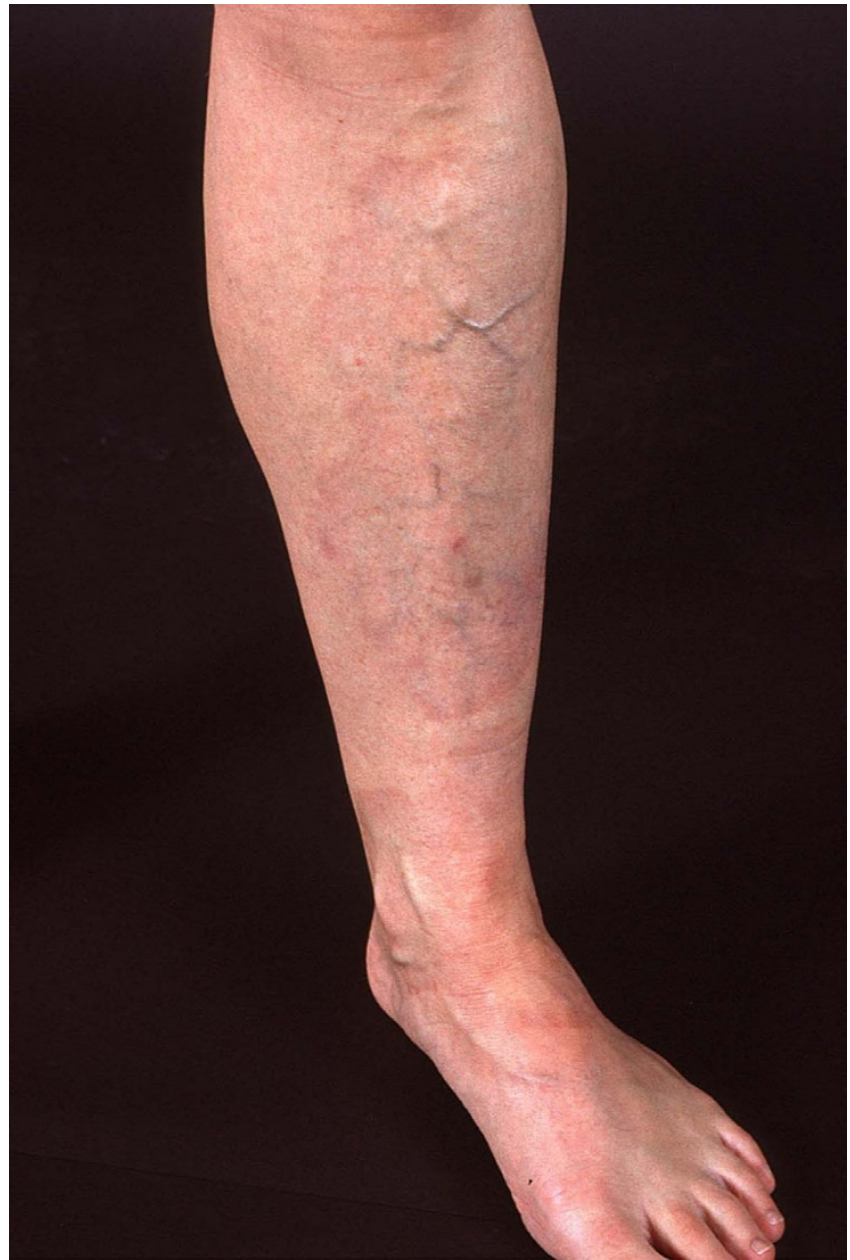

Figure 2

Almost complete clearance of disseminated granuloma annulare after 3 months of therapy with fumaric acid esters.

tablet form using two formulations differing in strength (low strength tablets: $30 \mathrm{mg}$ dimethylfumarate, $67 \mathrm{mg}$ monoethylfumarate Ca salt, $5 \mathrm{mg}$ monoethylfumarate $\mathrm{Mg}$ salt, $3 \mathrm{mg}$ monoethylfumarate $\mathrm{Zn}$ salt; high strength tablets: $120 \mathrm{mg}$ dimethylfumarate, $87 \mathrm{mg}$ monoethylfumarate Ca salt, $5 \mathrm{mg}$ monoethylfumarate $\mathrm{Mg}$ salt, $3 \mathrm{mg}$ monoethylfumarate Zn salt), supplied as Fumaderm ${ }^{\circledR}$ initial and Fumaderm ${ }^{\circledR}$ (Fumedica GmbH, Herne, Germany) [6]. Dosage of FAE was performed according to the standard therapy regimen for psoriasis patients displayed in Table 1. After two months, a complete clearance of skin lesions on the abdomen was achieved. Long-standing lesions on the legs improved after three-month therapy (Fig. 2). No subjective side effects were observed during treatment. Regular laboratory investigations, including differentiate blood count and kidney function, did not revealed abnormal findings during therapy, with the exception of slight lymphocytopenia. After discontinuation of 
treatment with FAE the patient remained in remission during a six-month follow up period.

Table I: Dosage schedule of fumaric acid esters used for the presented patient with disseminated granuloma annulare

$\begin{array}{llll}\text { Week Morning* Noon* }{ }^{*} \text { Evening* } & \begin{array}{l}\text { FAE formula- } \\ \text { tion }\end{array}\end{array}$

$\begin{array}{llccl}1 & 1 & - & - & \text { Fumaderm }{ }^{\circledR} \text { initial } \\ 2 & 1 & - & 1 & \text { Fumaderm }{ }^{\circledR} \text { initial } \\ 3 & 1 & 1 & 1 & \text { Fumaderm }{ }^{\circledR} \text { initial } \\ 4 & 1 & - & - & \text { Fumaderm } \\ 5 & 1 & - & 1 & \text { Fumaderm } \\ & \\ 6-12 & 1 & 1 & 1 & \text { Fumaderm } \\ \end{array}$

$*=$ number of tablets

\section{Discussion}

FAE has been shown to be an effective therapy option in patients with severe psoriasis vulgaris $[6,7]$. During therapy with fumaric acid a persistent decrease in the lymphocyte count and stimulation of TH2 cytokine responses have been observed. Since psoriasis is regarded as a TH1type inflammatory disorder, the immunomodulation away from the TH1 cytokine IFN- $\gamma$ to the TH 2 cytokine IL10 may lead to improvement of the disease. Furthermore the anipsoriatic activity of fumaric acid may also be mediated by diminishing proinflammatory cytokine overexpression and the antigen-presenting capacity of monocytes and macrophages $[8,9]$.

It has been reported that FAE induce apoptosis in human dentritic cells as well as keratinocytes [10]. Histopathologically, localized granuloma as well as DGA are characterized by lymphohistiocytic and monocytic infiltrates that form palisading granulomas with central necrobiotic changes. In a recent study, numerous apoptotic macrophages have been observed within the necrobiotic areas [11]. A popular view concerning pathogenesis holds that granuloma annulare is based on a delayed-type hypersensitivity reaction to as yet undefined cutaneous antigens. Phototherapy (e.g., psoralen plus ultraviolet-A radiation, ultraviolet- A1 radiation) is effective in DGA and is known to suppress delayed hypersensitivity responses in the skin [3-5]. Previous findings suggest that a T cell-mediated immune response producing cytokines may be the dominant pathogenic factor in granuloma annulare [12]. Thus the efficacy of FAE in DGA may be mediate by similar immunomodulatory mechanisms that are observed in the treatment of psoriasis. Notably it has been observed that treatment with FAE was also effective in cutaneous sarcoidosis and necrobiosis lipoidica which are closely related to granuloma annulare U. Nowack, MD, and T.
Gambichler, MD; unpublished data). Schulze-Dirks and Petzoldt [13] reported a female with a one-year history of DGA which resolved after six-week treatment of FAE. Since our patient had long-standing DGA, which was recalcitrant to potentially helpful therapeutic modalities, we do not consider that the therapeutic effect was due to spontaneous resolution. It has been demonstrated that FAE are well tolerated drugs suitable for long-term management (> 6 months) in psoriasis. Subjective adverse effects such as flushing and gastrointestinal symptoms are frequently observed. Relative lymphocytopenia is the most frequent laboratory finding in long-term users. Therefore therapy with FAE should only be performed under controlled conditions [14]. FAE are a potentially beneficial therapeutic option for patients with recalcitrant DGA. Controlled trials are however necessary to fully explore the efficacy, optimal dosage, and safety of FAE in the treatment of DGA.

\section{List of abbreviations}

DGA: disseminated granuloma annulare

FAE: fumaric acid esters

\section{Competing interests}

None declared

\section{References}

I. Dabski K, Winkelmann RK: Generalized granuloma annulare: Histopathology and immunology. Systematic review of 100 cases and comparison with localized granuloma annulare. J Am Acad Dermatol. 1989, 20:39-47

2. Smith D, Downie JB, DiCostanzo D: Granuloma annulare. Int J Dermatol. 1997, 36:326-333

3. Muchenberger S, Schöpf E, Simon JC: Phototherapy with UV-A-I for generalized granuloma annulare. Arch Dermatol. 1997, 133:1605

4. Salomon N, Walchner M, Messer G, Plewig G, Röcken M: BathPUVA therapy of granuloma annulare. Hautarzt 1999, 50:275279

5. Gambichler T, Menzel S: Cream PUVA in granuloma annulare. Z Dermatol. 1999, I 85:124-127

6. Mrowietz U, Christophers E, Altmeyer P: Treatment of severe psoriasis with fumaric acid esters: scientific background and guidelines for therapeutic use. Br J Dermatol. 1999, I 4 I:424-429

7. Altmeyer P, Matthes U, Pawlak F, Hoffmann K, Frosch PJ, Ruppert P, et al: Antipsoriatic effect of fumaric acid derivates. J Am Acad Dermatol. 1994, 30:977-98।

8. De Jong R, Bezemer AC, Zomerdijk PL, van de Pouw-Kraan, Ottenhoff HM, Nibbering PH: Selective stimulation of T helper 2 cytokine responses by anti-psoriasis agent monomethylfumarate. Eur J Immunol. 1996, 26:2067-2074

9. Asadullah K, Schmid H, Friedrich M, Randow F, Volk H, Sterry W, et al: Influence of monomethylfumarate on monocytic cytokine formation - explanation for adverse and therapeutic effects in psoriasis. Arch Dermatol Res. 1997, 289:623-630

10. Zhu K, Mrowietz U: Inhibition of dentritic cell differentiation by fumaric acid esters. J Invest Dermatol 200 I, I I 6:203-208

II. Fayyazi A, Schweyer S, Eichmeyer B, Herms ], Hemmerlein B, Radzun $\mathrm{HJ}$, Berger H: Expression of IFNgamma, coexpression of TNFalpha and matrix metalloproteinases and apoptosis of $\mathrm{T}$ lymphocytes and macrophages in granuloma annulare. Arch Dermatol Res 2000, 292:384-390

12. Buechner SA, Winkelmami RK, Banks PM: Identification of T-cell subpopulations in granuloma annulare. Arch Dermatol. 1983, I | 9:125-128 
13. Schulze-Dirks A, Petzoldt D: Disseminated granuloma annulare - successful therapy with fumaric acid esters. Hautarzt 200I, 52:228-230

14. Thio HB, van der Schroeff JG, Nugteren-Huying WM, Vermeer B]: Long-term systemic therapy with dimethylfumarate and monoethylfumarate (Fumaderm ${ }^{\circledR}$ ) in psoriasis. J Eur Acad Dermatol Venereol 1995, 4:35-40
Publish with BioMed Central and every scientist can read your work free of charge

"BioMedcentral will be the most significant development for disseminating the results of biomedical research in our lifetime." Paul Nurse, Director-General, Imperial Cancer Research Fund

Publish with BMC and your research papers will be:

- available free of charge to the entire biomedical community

- peer reviewed and published immediately upon acceptance

- cited in PubMed and archived on PubMed Central

- yours - you keep the copyright

BiolMedcentral.com editorial@biomedcentral.com 